\title{
Evaluation of the Antimicrobial Efficacy of Titanium Dioxide Nanoparticles on the Surfaces of Public Toilets
}

\author{
Omar Bashir Ahmed \\ Department of Environmental and Health Research, The Custodian of the Two Holy Mosques Institute for Hajj and Umrah \\ Research, Umm Al-Qura University, Makkah, KSA \\ Email: abuaglah1@hotmail.com
}

How to cite this paper: Ahmed, O.B. (2018) Evaluation of the Antimicrobial Efficacy of Titanium Dioxide Nanoparticles on the Surfaces of Public Toilets. Green and Sustainable Chemistry, 8, 32-38.

https://doi.org/10.4236/gsc.2018.81003

Received: December 17, 2017

Accepted: January 31, 2018

Published: February 2, 2018

Copyright $\odot 2018$ by author and Scientific Research Publishing Inc. This work is licensed under the Creative Commons Attribution International License (CC BY 4.0).

http://creativecommons.org/licenses/by/4.0/

\section{(c) () Open Access}

\begin{abstract}
The infection control in surfaces of public toilets environment is a matter of great concern and a major challenge, especially during mass gatherings. The present study aimed to evaluate the antimicrobial efficacy of titanium dioxide nanoparticles coating on environmental surfaces of public toilets during Hajj time. A pilot study has been designed to evaluate the antimicrobial efficacy of titanium dioxide nanoparticles on the surfaces of public toilets. The results showed a significant reduction in colony-count of the test samples. Maximum average reduction count of test microbes of the seats and walls reached (99.7\%) while that of the doors reached $(99.1 \%)$ which was statistically significant $(\mathrm{P}$ value $=0.001)$. It was concluded that there was a marked effect of a mixed $\mathrm{TiO} 2$ coating on reducing the microbial count at the surfaces of public toilets environments. Further research on efficacy against specific organisms, intestinal parasites, fungi, viruses and bacteriophage is recommended.
\end{abstract}

\section{Keywords}

Titanium Dioxide, Public Toilets, Colony Count, Nanoparticles

\section{Introduction}

Public bathrooms have the most amounts of hidden germs even cleaned because this space is shared with a whole lot of people who may have infectious diseases [1]. Health experts point out that even clean-looking, bathrooms are dangerous if not being well disinfected. In the best conditions, they may produce bacteria that become a source for many infections [1] [2]. So that the infection control in surfaces of public toilets environment is a matter of great concern and a major 
challenge, especially in crowded area because such environments can be potential sources for other epidemic diseases. During Hajj, more than 2.5 million people from different parts of the world were gathered in Makkah. The toilets should be adequate in number, conveniently located, well provided, safe, easily accessible, free of infections. Routine cleaning and manual disinfection in the public toilets are often insufficient. Because many chemicals are of limited use and do not meet all the required criteria. Many types of disinfectants products are available but with moderate or even insufficient antimicrobial action [3] [4]. The introduction of optimal cleansing products and processes is critical to control and prevent infections [5]. Further efforts are required to improve the traditional methods in decontamination of toilet surfaces. New methodologies and techniques are needed with "permanent" antimicrobial effect without risk of generating micro-organisms resistance [6] [7]. Titanium dioxide $\left(\mathrm{TiO}_{2}\right)$ is non-toxic, available, cost effective, chemically stable and with favorable properties [8]. It is a semiconductor and has been proved to be an excellent photocatalyst degrading organic pollutants and effective antibiotic against bacteria, fungi, viruses, and bacteriophage [9]. Once subjected to light, the negative electrons and oxygen atom will combine into $\mathrm{O}^{2-}$; the positive holes and water will generate hydroxyl radicals $\left(\mathrm{OH}^{-}\right)$[10]. Both of $\mathrm{O}^{2-}$ and $\mathrm{OH}^{-}$molecules are reactive, so they will combine with any organic material around the surface of the photocatalyst and turn into carbon dioxide and water. The consequence of this reaction is the decomposition of organic matters, removal of odor, killing of microorganisms [8] [10]. There are no studies to date, to the author knowledge, which evaluate the efficacy of $\mathrm{TiO}_{2}$ in the public toilet environment. So the aim of the present pilot study was to evaluate the antimicrobial efficacy of titanium dioxide nanoparticles coating on environmental surfaces on selected public toilets.

\section{Materials and Methods}

A pilot study has been designed to evaluate the microbial count of surfaces in toilets after coating with titanium dioxide. The microbiological survey was conducted in four public toilets (two tests and two controls) in Makkah during Hajj time. Three surfaces (seats, walls, and doors) within each toilet were selected for sampling. All surfaces were assayed once time daily. The Four toilets were thoroughly cleaned using a detergent solution and left to dry. Cultures were taken before and after coating from marked sites per toilet (seats, walls, and doors). The sampling area was delineated with a sterile stainless steel template which exposed a surface area of $50 \mathrm{~cm}^{2}$ [11]. All surfaces were swabbed using plain cotton swabs and inoculated into vials containing $1 \mathrm{~mL}$ of sterile water. After sampling, the swabs were labeled and transported to the Microbiology Laboratory at environment and health research department, Umm Alqura University, 15 to $45 \mathrm{~min}$ of sampling and stored at $4^{\circ} \mathrm{C}$ until testing. All samples were analyzed within $1 \mathrm{~h}$ of arrival at the laboratory. Each vail $(1 \mathrm{ml})$ was plated on aerobic count Petrifilm plates ( $3 \mathrm{M}$ Microbiology), and plates were incubated at $32^{\circ} \mathrm{C}$ 
for $48 \mathrm{~h}$. Upon the completion of incubation, plates were counted on a standard colony counter. The two test toilets then were coated using a high-pressure spraying system. First, a primer was sprayed on all surfaces and left to dry, then the mixed $\mathrm{TiO}_{2}$ coating, containing silver supported zeolite, peroxotitanic acid and water (Miracle Titanium MVX, Maeda Kougyou, Kitakyushu, Japan), was applied on exactly the same surfaces as the primer. After at least $2 \mathrm{~h}$ of drying, the toilets could be used by people. Cultures were taken again after one day and then every 2 days in the first week, afterwards cultures were collected weekly for two months.

\section{Statistical Analysis}

Statistics were performed using SPSS 22 for windows to perform independent t-tests analyses to identify significant differences between controls and tests. ANOVA test analysis was performed to identify significant bacterial reduction between doors, walls and seats after $\mathrm{TiO}_{2}$ coating.

\section{Results}

After the application of $\mathrm{TiO}_{2}$, the results showed a significant dropping in log cfus $/ 50 \mathrm{~cm}^{2}$ of the test samples while the controls have almost remained high or without changes (Figures 1-3) which was statistically significant ( $p$ value $=$ 0.00). Maximum average reduction count of the seats and walls reached $(99.7 \%)$ while that of the doors reached $(99.1 \%)$ with significant $P$ value $(0.001)$ as showed in Table 1 .

\section{Discussion}

The present pilot study evaluated effects of a $\mathrm{TiO}_{2}$ coating on surface contamination of selected public toilets surfaces (walls, doors and seats). The results showed that the level of the bacterial count of the pre-coating swabs taken from all surfaces (tests and controls) was close and very high. That is not surprising

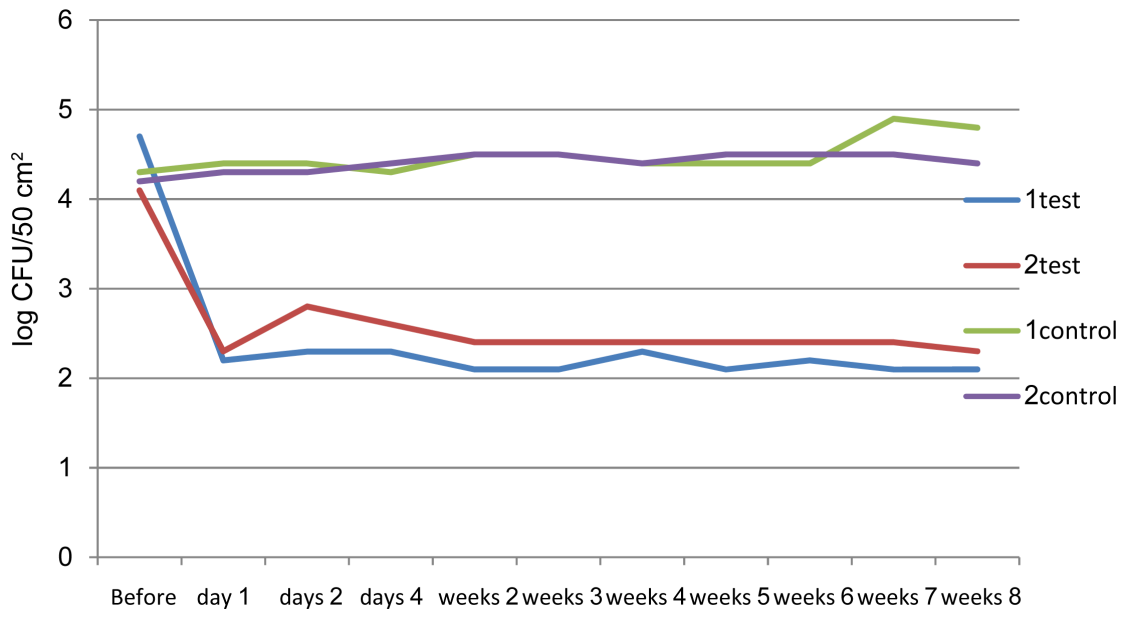

Figure 1. Reduction in Bacterial count of the walls surfaces after coating with $\mathrm{TiO}_{2}$. 


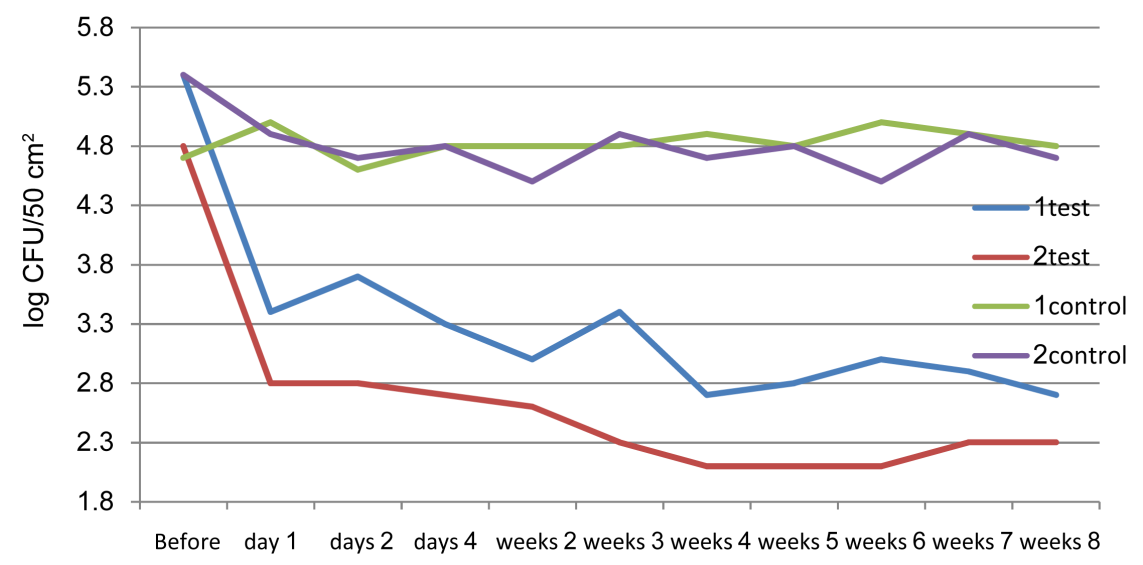

Figure 2. Reduction in Bacterial count of the seats surfaces after coating with $\mathrm{TiO}_{2}$.

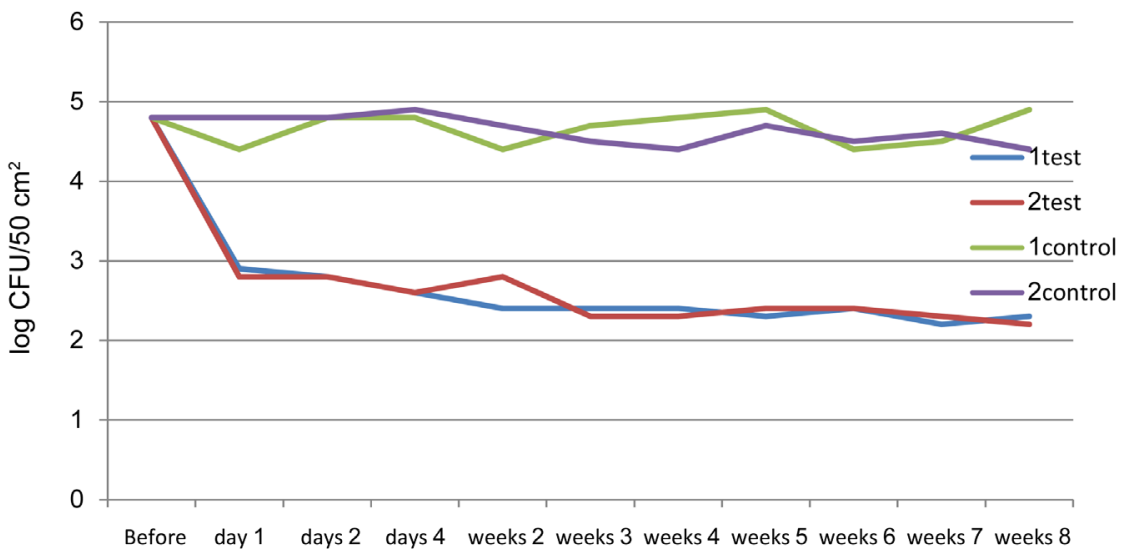

Figure 3. Reduction in Bacterial count of the doors surfaces after coating with $\mathrm{TiO}_{2}$.

Table 1. The average reduction of bacterial count in different surfaces after coating with $\mathrm{TiO}_{2}$.

\begin{tabular}{lccc}
\hline Intervals & \multicolumn{3}{c}{ Reduction (\%) } \\
\hline & Doors & walls & seats \\
\hline After one day & 99.0 & 99.0 & 98.9 \\
After 2 days & 97.3 & 98.5 & 99.0 \\
After 4 days & 98.2 & 99.2 & 99.4 \\
After 2 weeks & 98.9 & 99.5 & 99.3 \\
After 3 weeks & 98.9 & 99.3 & 99.6 \\
After 4 weeks & 98.8 & 99.8 & 99.6 \\
After 5 weeks & 98.9 & 99.8 & 99.6 \\
After 6 weeks & 98.8 & 99.7 & 99.6 \\
After 7 weeks & 98.9 & 99.7 & 99.7 \\
After 8 weeks & 99.1 & 99.7 & 99.7 \\
\hline
\end{tabular}

because bathrooms and toilets contain large numbers of intestinal pathogens in addition to the bacteria that can be shed from the skin, saliva, mucous and nasal 
secretions [12] [13]. Both detergent- and disinfectant-based cleaning can help to control these pathogens but traditional cleaning methods are notoriously inefficient for decontamination, and new approaches have been proposed, such as self-sanitizing surfaces [7] [14] [15].

Creating "self-disinfecting surfaces" means to coat them with UV-activated $\mathrm{TiO}_{2}$, which undergoes photocatalytic reactions and oxidizes volatile organic compounds and the microorganisms in the surfaces of public toilets.

After the application of $\mathrm{TiO}_{2}$, the results of the present study showed a significant reduction in colony-count as compared to the cultures collected before the application of $\mathrm{TiO}_{2}$ (Figures 1-3) while the controls have almost remained high or no changes with significant difference $(\mathrm{p}$ value $=0.00$ ). Maximum average reduction count of test microbes of the seats and walls reached (99.7\%) while that of the doors reached (99.1\%) (Table 1) which was statistically significant (P value $=0.001)$. Although the bacterial count has been increased during the study period due to the excessive usage of the toilets during the study period, the average level of bacteria never returned to those observed before treatment (Figures 1-3). No previous studies about creating "self-disinfecting surfaces" in the toilets surfaces but the application has been done in hospital environments in ICU surfaces [16] [17] with marked variations in results. Tamimi et al. [16], and Sujata and Jack [18], concluded that the use of $\mathrm{TiO}_{2}$ for environmental sanitation is effective and could reduce the risk of pathogenic microorganisms and the product was found to have persisted over 15 weeks in reducing the total number of bacteria on surfaces. For instance, Kim et al. [19], demonstrated that $\mathrm{TiO}_{2}$ in combination with UV showed a significant decrease in bacterial count after short time. Kühn et al. [20], showed that the bacterial count reduced by approximately 6 logs after treatment with photo catalytic titanium dioxide. Chuaybamroong et al. [21] concluded that A 60\% - 100\% microbe reduction can be achieved to provide better indoor air quality for hospitals, offices, and domestic applications. However, all these studies showed increased efficacy of $\mathrm{TiO}_{2}$ as an antimicrobial agent in the presence of UV or light. In contrast, de Jong et al. [17] and Leng et al. [22] reported that $\mathrm{a} i O_{2}$ did not influence the microbial colonization of surfaces in an ICU and on the positive culture results. These variations in the results may be due to many factors that influence the efficacy of $\mathrm{TiO}_{2}$ photocatalysis such as air humidity, UV light intensity and wavelength, thickness of the coating, target organism, initial concentration and composition of the coated surface. The present study was limited by missing some specific information on the characterization of the product. In conclusion, the mixed $\mathrm{TiO}_{2}$ coating showed good effect of on reducing the microbial count of surfaces in public toilets environments. Further research on efficacy against specific organisms, intestinal parasites, fungi, viruses and bacteriophage is recommended.

\section{References}

[1] Gerhardts, A., Hammer, T., Balluff, R.C., Mucha, H. and Hoefer, D. (2012) A Model 
of the Transmission of Micro-Organisms in a Public Setting and Its Correlation to Pathogen Infection Risks. Journal of Applied Microbiology, 112, 614-621. https://doi.org/10.1111/j.1365-2672.2012.05234.x

[2] Barker, J. and Jones, M.V. (2005) The Potential Spread of Infection Caused by Aerosol Contamination of Surfaces after Flushing a Domestic Toilet. Journal of Applied Microbiology, 99, 339-347. https://doi.org/10.1111/j.1365-2672.2005.02610.x

[3] Ahmed, O.B. and Mashat, B.H. (2015) Efficacy of Three Disinfectant Agents against Contaminating Pathogens Isolated from Public Toilets. Global Advanced Research Journal of Medicine and Medical Sciences, 4, 473-476.

[4] Pitten, F.A., Werner, H.P. and Kramer, A. (2003) Astandardized Test to Assess the Impact of Different Organic Challenges on the Antimicrobial Activity of Antiseptics. Journal of Hospital Infection, 55, 108-115. https://doi.org/10.1016/S0195-6701(03)00260-3

[5] Simões, M., Simões, L.C., Cleto, S., Machado, I., Pereira, M.O. and Vieira, M.J. (2007) Antimicrobial Mechanisms of Ortho-Phthalaldehyde Action. Journal of Basic Microbiology, 47, 230-242. https://doi.org/10.1002/jobm.200610280

[6] Zollfrank, C., Gutbrod, K., Wechsler, P., et al. (2012) Antimicrobial Activity of Transition Metal Acid $\mathrm{MoO}_{3}$ Prevents Microbial Growth on Material Surfaces. Materials Science and Engineering C: Materials for Biological Applications, 32, 47-54. https://doi.org/10.1016/j.msec.2011.09.010

[7] Humphreys, H. (2014) Self-Disinfecting and Microbiocide-Impregnated Surfaces and Fabrics: What Potential in Interrupting the Spread of Healthcare-Associated Infection? Clinical Infectious Diseases, 58, 848-853.

https://doi.org/10.1093/cid/cit765

[8] Daghrir, R., Drogui, P. and Robert, D. (2013) Modified $\mathrm{TiO}_{2}$ for Environmental Photocatalytic Applications: A Review. Industrial \& Engineering Chemistry Research, 52, 3581-3599. https://doi.org/10.1021/ie303468t

[9] Paspaltsis, I., Kotta, K., Lagoudaki, R., Grigoriadis, N., Poulios, I. and Sklaviadis, T. (2006) Titanium Dioxide Photocatalytic Inactivation of Prions. Journal of General Virology, 87, 3125-3130. https://doi.org/10.1099/vir.0.81746-0

[10] Visai, L., De Nardo, L., Punta, C., Melone, L., Cigada, A., Imbriani, M. and Arciola, C.R. (2011) Titanium Oxide Antibacterial Surfaces in Biomedical Devices. The International journal of Artificial Organs, 34, 929-946.

[11] Cosby, C.M., Costello, C.A., Morris, W.C., Haughton, B., Devereaux, M.J., Harte, F. and Davidson, P.M. (2008) Microbiological Analysis of Food Contact Surfaces in Child Care Centers. Applied and Environmental Microbiology, 74, 6918-6922. https://doi.org/10.1128/AEM.00547-08

[12] Costello, E.K., Lauber, C.L., Hamady, M., Fierer, N., Gordon, J.I. and Knight, R. (2009) Bacterial Community Variation in Human Body Habitats across Space and Time. Science, 326, 1694-1697. https://doi.org/10.1126/science.1177486

[13] Flores, G.E., Bates, S.T., Knights, D., Lauber, C.L., Stombaugh, J., Knight, R. and Fierer, N. (2011) Microbial Biogeography of Public Restroom Surfaces. PLoS ONE, 6, e28132. https://doi.org/10.1371/journal.pone.0028132

[14] Weber, D.J. and Rutala, W.A. (2013) Self-Disinfecting Surfaces: Review of Current Methodologies and Future Prospects. American Journal of Infection Control, 41, S31-S35. https://doi.org/10.1016/j.ajic.2012.12.005

[15] Dancer, S.J. (2014) Controlling Hospital-Acquired Infection: Focus on the Role of the Environment and New Technologies for Decontamination. Clinical Microbiology Reviews, 27, 665-690. https://doi.org/10.1128/CMR.00020-14 
[16] Tamimi, A.H., Carlino, S. and Gerba, C.P. (2014) Long-Term Efficacy of a Self-Disinfecting Coating in an Intensive Care Unit. American Journal of Infection Control, 42, 1178-1181. https://doi.org/10.1016/j.ajic.2014.07.005

[17] de Jong, B., Meeder, A.M., Koekkoek, K.W.A.C., Schouten, M.A., Westers, P. and van Zanten, A.R.H. (2017) Pre-Post Evaluation of Effects of a Titanium Dioxide Coating on Environmental Contamination of an Intensive Care Unit: The TITANIC Study. Journal of Hospital Infection. https://doi.org/10.1016/j.jhin.2017.04.008

[18] Sujata, S.A. and Jack, N.A. (2015) Titanium Dioxide Nanoparticles as an Environmental Sanitizing Agent. Journal of Microbial and Biochemical Technology, 7, 61-64.

[19] Kim, B., Kim, D., Cho, D. and Cho, S. (2003) Bactericidal Effect of $\mathrm{TiO}_{2}$ Photocatalyst on Selected Food-Borne Pathogenic Bacteria. Chemosphere, 52, 277-281. https://doi.org/10.1016/S0045-6535(03)00051-1

[20] Kühn, K.P., Chaberny, I.F., Massholder, K., Stickler, M., Benz, V.W., Sonntag, H.G. and Erdinger, L. (2003) Disinfection of Surfaces by Photocatalytic Oxidation with Titanium Dioxide and UVA Light. Chemosphere, 53, 71-77.

https://doi.org/10.1016/S0045-6535(03)00362-X

[21] Chuaybamroong, P., Chotigawin, R., Supothina, S., Sribenjalux, P., Larpkiattaworn, S. and $\mathrm{Wu}, \mathrm{C.Y} .(2010)$ Efficacy of Photocatalytic HEPA Filter on Microorganism Removal. Indoor Air, 20, 246-254. https://doi.org/10.1111/j.1600-0668.2010.00651.x

[22] Leng, C.W., Soe, T.A., Wui, L.W., Yen, J.L.F., Kurup, A., Lin, L.M., Tan, A.L. and Ong, B.C. (2013) Efficacy of Titanium Dioxide Compounds in Preventing Environmental Contamination by Meticillin Resistant Staphylococcus aureus (MRSA). International Journal of Infection Control, 9, 1-8. 